\title{
Veterinary homeopathy: Systematic review of medical conditions studied by randomised trials controlled by other than placebo
}

\author{
Robert T Mathie ${ }^{1 *}$ and Jürgen Clausen ${ }^{2}$
}

\begin{abstract}
Background: No systematic review has previously been carried out on randomised controlled trials (RCTs) of veterinary homeopathy in which the control group was an intervention other than placebo (OTP). For eligible peer-reviewed RCTs, the objectives of this study were to assess the risk of bias (RoB) and to quantify the effect size of homeopathic intervention compared with an active comparator or with no treatment.

Methods: Our systematic review approach complied fully with the PRISMA 2009 Checklist. Cochrane methods were applied to assess RoB and to derive effect size using standard meta-analysis methods. Based on a thorough and systematic literature search, the following key attributes of the published research were distinguished: individualised homeopathy $(n=1 R C T)$ /non-individualised homeopathy $(n=19)$; treatment $(n=14) /$ prophylaxis $(n=6)$; active controls $(n=18) /$ untreated controls $(n=2)$. The trials were highly diverse, representing 12 different medical conditions in 6 different species.

Results: No trial had sufficiently low RoB to be judged as reliable evidence: 16 of the 20 RCTs had high RoB; the remaining four had uncertain RoB in several domains of assessment. For three trials with uncertain RoB and without overt vested interest, it was inconclusive whether homeopathy combined with conventional intervention was more or was less effective than conventional intervention alone for modulation of immune response in calves, or in the prophylaxis of cattle tick or of diarrhoea in piglets.

Conclusion: Due to the poor reliability of their data, OTP-controlled trials do not currently provide useful insight into the effectiveness of homeopathy in animals.
\end{abstract}

Keywords: Veterinary homeopathy, Randomised controlled trials, Systematic review

\section{Background}

Our group's systematic analysis of the published literature of randomised controlled trials (RCTs) in veterinary homeopathy identified 38 peer-reviewed papers that we regarded as potentially eligible for detailed review [1]. As emphasised in that article, no systematic review of this research evidence had ever previously been carried out.

We have recently reported our review findings for 18 placebo-controlled trials of veterinary homeopathy [2, 3], in which there was indecisive evidence whether the use of homeopathy in animals is distinguishable from placebos.

\footnotetext{
* Correspondence: rmathie@britishhomeopathic.org

'British Homeopathic Association, Hahnemann House, 29 Park Street West, Luton LU1 3BE, UK

Full list of author information is available at the end of the article
}

The present paper reports our results from a similarly detailed appraisal and analysis of the remaining papers, each of which reported an RCT where the control group was an intervention other than placebo (OTP).

Our approach here reflects our original literature analysis [1] and so we continue to distinguish peer-reviewed from non-peer-reviewed articles, individualised from non-individualised homeopathy, and treatment from prophylaxis. We thus report our findings from the appraisal of peer-reviewed, OTP-controlled trials of veterinary homeopathy (individualised or non-individualised, treatment or prophylaxis).

Our objective firstly was to assess the study quality (risk of bias) of each eligible RCT [4], together with the direction and statistical significance of treatment or 
prophylactic effect. For suitable groupings of RCTs (per species-specific medical condition; per type of control group), we aimed then to determine pooled summary statistics by meta-analysis methods and to examine their sensitivity to study quality. In both objectives, our emphasis was focused on trials that satisfied our criteria for reliable evidence $[2,3]$.

\section{Methods}

Methods comply with the PRISMA (Preferred Reporting Items for Systematic Reviews and Meta-Analyses) 2009 Checklist (see Additional file 1) [5]. They are compatible with our previously published papers in this series of veterinary reviews [1-3], and with our protocol-based systematic reviews and meta-analyses of homeopathy RCTs in human medicine $[6,7]$.

Matters connected with study eligibility, research design categories and the literature search strategy were described in detail in our earlier paper [1]. Only brief descriptions are therefore given here, with additional information that is specific to the methods used for the present paper.

\section{Identifying papers for full data extraction}

Each of the following electronic databases was searched up to and including March 2011 [1], with a follow-up search of the same databases up to the end of 2013: $A M E D$, CINAHL, CENTRAL, Embase, HomVetCR, LILACS, PubMed, Science Citation Index, Scopus. There were no language restrictions. During the peer-review process for the current paper, we became aware that relevant additional literature might be contained in $C A B$ Abstracts [8], which we therefore searched up to and including May 2015, and with the intention to update our review and analysis if significant numbers of eligible RCTs were revealed.

In our original literature search [1], 20 records of trials were identified as satisfying the key acceptance criteria for the present systematic review: substantive report of clinical treatment or prophylaxis trial for any medical condition or species in veterinary homeopathic medicine, randomised, controlled by OTP, and published in a peerreviewed journal. One of us screened and categorised each of these potentially relevant papers (plus those identified in our follow-up search - see Results) to assess their eligibility for full data extraction. The other independently appraised these decisions; any differences of opinion were resolved by consensus discussion.

\section{Exclusion criteria prior to full data extraction}

- Research using radionically prepared 'homeopathic' medicines.

- The tested intervention is homeopathy combined with other (complementary or conventional) medicine or therapy.

\section{Data extraction and management}

The authors of eligible RCT papers were not approached for clarification on unclear or missing facets of their methods or results [4], though original authors' crossreference to their previously published study methods were taken into account as appropriate [2]. For each of two assessors working independently, relevant data were extracted and then recorded using a standardised data collection format (Microsoft Excel).

No paper reported more than one RCT. For a paper reporting an RCT that involved $>2$ groups of subjects, we typically pursued data extraction on only one pair of groups: trials that included an OTP as well as a placebo control group had been scrutinised previously $[2,3]$ and were not reappraised for the current study. For studies that comprised $>1$ homeopathy group, the total sample size reflects the total numbers of subjects in the homeopathy groups combined [9]. This was the approach in all relevant cases, i.e.: where the same homeopathic medicine was used, and with the same timing of administration but in different potency; where the same homeopathic medicine and potency was used, but with different timing of administration; where a different homeopathic medicine was used.

\section{Study appraisal \\ Assessment of risk of bias}

Using the standard criteria defined by Cochrane [4], extraction of information from each paper enabled us to answer the question, 'Is the study free from risk of bias?': 'Yes'; 'Unclear'; 'No'. The two assessors' independent judgments were mutually scrutinised and compared, with discrepancies between them resolved by consensus discussion. This approach applied to each of seven assessment domains: I, the method used to generate the random sequence; II, the method of allocation concealment used to implement the random sequence; IIIA, the blinding of trial personnel, including animal owner as appropriate; IIIB, the blinding of outcome assessors; IV, whether all the randomised patients are accounted for in the analysis; V, whether there is evidence of selective outcome reporting; VI, whether there is evidence of other bias, such as extreme data imbalance at baseline.

For domain IV, a trial was automatically regarded as no better than 'unclear' if there was greater than $20 \%$ participant attrition rate, irrespective of whether intention-totreat analysis had been carried out on the data. For domain $\mathrm{V}$, we based our judgment of reported outcomes on a comparison with the details given in the same paper's Methods section (original trial protocols have not been published in veterinary homeopathy). For the purposes of the current paper, we assessed domain V as 'No' (high risk of bias) if the main outcome data were not extractable for metaanalysis. The source of any research funding/sponsorship, 
or other vested interest such as personnel employment or contract, was not taken into account for risk-of-bias assessment (domain VI), but was reflected in the overarching assessment of risk of bias for each RCT.

\section{Assessment per trial for risk of bias}

Using the Cochrane approach [4], each trial was designated overall as follows: low risk of bias for all domains; uncertain risk of bias for one or more domains, and no evident risk of bias in any domain; high risk of bias for one or more domains. A trial with overall low risk of bias comprised reliable evidence. For a trial that did not display high risk of bias in any domain, we regarded its evidence as reliable if the study was assessed as free of bias for each of domains I, IIIA, IIIB and IV [2, 3].

\section{Outcome assessment and reporting}

\section{Identification of 'main outcome measure' per trial}

For the purposes of risk-of-bias assessment and for assessment of treatment effect, we identified for each trial a single 'main outcome measure' using a refinement of the approaches adopted by Linde et al. [10] and by Shang et al. [11]. The main outcome measure of each trial was based on a hierarchical ranking order (consistent with the World Health Organization's [12] classification system for levels of functioning linked to health condition), and as previously described [2]. This approach ensured that the most clinically important outcome was selected per trial, and also avoided the problem of outcome multiplicity [13].

Unless otherwise indicated, the single end-point (as determined from the start of the intervention) associated with the designated 'main outcome measure' was taken as the last follow-up at which data were reported for that outcome [2].

\section{Analysis of outcomes}

\section{Summary effect measures for 'main outcome'}

For each eligible trial, the effect size was taken as the difference between the homeopathy group and the control group at the designated end-point of the trial, as follows [2]:

- For a dichotomous measure: odds ratio (OR), with $95 \%$ confidence interval (CI);

- For a continuous measure: standardised mean difference (SMD), with $95 \%$ CI.

If the original paper did not provide adequate information on the designated main outcome measure to enable data extraction, that trial's outcome was classified as 'not estimable' and a further potentially estimable outcome was not sought.

Under the separate group headings of individualised homeopathy and non-individualised homeopathy, and for the categories below in which there was $>1$ RCT of a given study design that had extractable data, we aimed to determine pooled summary statistics for:

- Disease-specific treatment effects per species;

- Disease-specific prophylactic effects per species.

All calculations and analyses were performed using Review Manager 5.2 (Cochrane). Given our anticipation of heterogeneous data for intervention effects, the random-effects (rather than fixed-effects) model was planned for all meta-analyses [14].

\section{Reflecting study quality overall}

Our main analyses used only the data extracted from trials without evident high risk of bias. It was intended that our primary conclusions would be based solely on trials with reliable evidence and without overt vested interest (not funded, directly or indirectly, by a homeopathic pharmacy).

\section{Direction of effect of treatment/prophylaxis per trial}

Care was taken faithfully to represent the correct direction of change per trial: e.g. an effect favouring homeopathic intervention was higher rate of recovery but lower faecal egg count. The arithmetic content of the OR, or the sign of the SMD, was adjusted appropriately if so indicated.

We regarded each RCT as a superiority trial [15] unless the original paper stated explicitly in its Methods section that the study was designed as an equivalence or non-inferiority trial [16, 17], with corresponding power calculation. For each of three study designs (and regarding each design as a superiority trial), we adopted the following rationale for interpretation of the three possible statistical findings:

Statistical finding (i): $P \leq 0.05$ : Direction of effect toward homeopathy

a. Study design: active control. Homeopathy is more effective than a conventional intervention;

b. Study design: [homeopathy plus active control] versus active control (' $[A+B]$ versus $B$ '). Homeopathy combined with conventional intervention is more effective than conventional intervention alone;

c. Study design: no-treatment control. Homeopathy is more effective than no intervention.

Statistical finding (ii): $P \leq 0.05$ : Direction of effect toward control

a. Study design: active control. Homeopathy is less effective than a conventional intervention;

b. Study design: [homeopathy plus active control] versus active control (' $[A+B]$ versus $B$ '). Homeopathy 
combined with conventional intervention is less effective than conventional intervention alone;

c. Study design: no-treatment control. Homeopathy is ineffective.

Statistical finding (iii): $P>0.05$ : Direction of effect toward either homeopathy or control

a. Study design: active control. Inconclusive whether homeopathy is more or is less effective than a conventional intervention [18, 19];

b. Study design: [homeopathy plus active control] versus active control (' $[A+B]$ versus $B$ '). Inconclusive whether homeopathy combined with conventional intervention is more or is less effective than conventional intervention alone;

c. Study design: no-treatment control. Inconclusive whether homeopathy is more or less effective than no treatment.

\section{Results}

\section{Demographic details}

Additional file 2 illustrates the PRISMA flowchart, which follows on from, and suitably updates [20], that in our earlier paper [1]; our current focus is on OTPcontrolled trials only. Two OTP-controlled trials were rejected from the current review due to their focus on homeopathy combined with another intervention: A29, Dreissman 2010; A30, Lepple 1984. A further two were excluded due to their focus on neither treatment nor prophylaxis: A33, Sharma 1987; A37, Trehan 1994. Four additional eligible records were identified in our follow-up search, and included in analysis. Our subsequent search of $C A B$ Abstracts, conducted during peer review of the current paper, revealed just one potentially eligible trial [21], which we did not consider further.

Table 1 details each of the 20 studies eligible for full systematic review: (i) individualised homeopathy/treatment $(\mathrm{n}=1)$; (ii) non-individualised homeopathy/treatment ( $\mathrm{n}=13)$; (iii) non-individualised homeopathy/ prophylaxis $(n=6)$. Data per trial include: nature of the homeopathic intervention; study setting; the RCT's source of funding. Our definitions of 'treatment' and 'prophylaxis' were as previously described [1]. All RCTs were identified as superiority trials, despite the fact that in some cases the original authors applied the terms 'equivalence trial' or 'non-inferiority trial' post-hoc in Results or in Discussion (A15, Faulstich 2006; A39, Braun, 2011).

Extreme diversity characterised the studies as regards species, medical condition, homeopathic medicine, and funding source. In the 20 eligible studies, 6 different species are represented: birds $(n=1)$; cattle $(n=11)$; dogs $(n=1)$; horses $(n=1)$; pigs $(n=4)$; sheep $(n=2)$. Twelve different conditions are represented. None of the trials had a clearly unbiased funding source; we identified overt vested interest in 10 of the 20 trials.

Table 2 includes: sample sizes; designated 'main outcome measure'; type of data (whether dichotomous or continuous); study endpoint. Diversity was again apparent, with large variation in sample sizes, main outcome, and timing of the study endpoint.

\section{Risk of bias}

Table 3 shows our risk-of-bias judgments for each eligible trial.

Many of the papers were written to such a poor standard that risk-of-bias assessments were sometimes challenging. No trial had low risk of bias in all of the Cochrane judgmental domains. Sixteen trials had high risk of bias in one or more domains. Four trials had merely uncertain risk of bias, and the uncertainty was evident in five domains per study (A31, Reis 2006; A32, Reis 2008; A34, Signoretti 2008; A36, Soto 2008). There was therefore no trial that could be designated as reliable evidence.

Only five of the 20 trials had adequate randomisation (domain I), and none of the trials had adequate allocation concealment (domain II) or personnel blinding (domain IIIA). See also Fig. 1 (Risk-of-bias summary graph).

\section{Analysis of outcomes}

Fifteen of the 20 trials had extractable data. Due to the diversity of medical conditions, species, types of homeopathic intervention, study designs and outcome measures, as well as the very unclear quality of the evidence, it was not appropriate to carry out meta-analysis on disease-specific intervention.

The direction of effect favoured homeopathy in 11 trials (statistically significantly so in four cases) and favoured control in four trials (statistically significantly so in zero cases) - see Table 4, in which the inference from the statistical findings is given by reference to the numbered study designs in Methods: Direction of effect of treatment/prophylaxis per trial.

\section{Trials with uncertain risk of bias}

In the absence of any trials with reliable evidence, our main attention has been forced on to the data extracted from three trials with uncertain risk of bias and without overt vested interest (Table 4a): A32, Reis 2008 (modulation of immune response to rabies vaccination in calves); A34, Signoretti 2008 (cattle tick); A36, Soto 2008 (diarrhoea in piglets). All three trials were in the category 'non-individualised/prophylaxis/' $[A+B]$ versus B' design. None of the three showed evidence of a difference between adjunctive homeopathy and active control alone, 
Table 1 Demographic details of 20 OTP-controlled RCTs in veterinary homeopathy

\section{i: Individualised/Treatment}

\section{Condition \\ Species Ref. First author Year Design}

\section{Control}

Antibiotic

and agalactia

\section{ii: Non-individualised/Treatment}

Condition

\begin{tabular}{|c|c|c|c|c|c|c|c|}
\hline $\begin{array}{l}\text { Diarrhoea } \\
\text { (neonatal) }\end{array}$ & Cattle & A42 & Lohr & 2012 & Active & Oral electrolytes & $\begin{array}{l}3 \text { complex preparations: Nux } \\
\text { vomica; Veratrum; Engystol }\end{array}$ \\
\hline $\begin{array}{l}\text { Diarrhoea } \\
\text { (neonatal) }\end{array}$ & Pigs & A14 & Coelho & 2009 & Active & Antibiotic & Phosphorus/E. coli \\
\hline $\begin{array}{l}\text { Ectoparasite } \\
\text { infestation }\end{array}$ & Cattle & A41 & Catto & 2013 & Active & Anthelmintic & $\begin{array}{l}2 \text { complex preparations } \\
\text { of various components } \\
\text { (mainly nosodes) }\end{array}$ \\
\hline $\begin{array}{l}\text { Ectoparasite } \\
\text { infestation }\end{array}$ & Cattle & A19 & Silva & 2008 & Active & Chemical dip & $\begin{array}{l}\text { 'Biotherapic' of Boophilus } \\
\text { microplus and } 14 \text { other } \\
\text { organisms }\end{array}$ \\
\hline $\begin{array}{l}\text { Foot-and-mouth } \\
\text { disease }\end{array}$ & Cattle & $\mathrm{A} 40$ & Lotfollahzadeh & 2012 & Active & $\begin{array}{l}\text { Anti-inflamatory } \\
\text { and antibiotic }\end{array}$ & Tarentula cubensis \\
\hline $\begin{array}{l}\text { Gastrointestinal } \\
\text { nematodes }\end{array}$ & Sheep & A21 & Zacharias & 2008 & Active & Anthelmintic & $\begin{array}{l}3 \text { remedies: Ferrum } \\
\text { phosphoricum, Arsenicum } \\
\text { album, Calcarea carbonica }\end{array}$ \\
\hline Lameness & Horses & A15 & Faulstich & 2006 & Active & $\begin{array}{l}\text { Hyaluronic } \\
\text { acid }\end{array}$ & $\begin{array}{l}\text { Complex of } 14 \text { homeopathically } \\
\text { prepared ingredients }\end{array}$ \\
\hline Mastitis & Cattle & A16 & Klocke & 2010 & Active & Teat-sealer & $\begin{array}{l}8 \text { remedies: Mercurius solubilis, } \\
\text { Lachesis mutus, Sulfur, Calcium } \\
\text { carbonicum, Calcium phosphoricum, } \\
\text { Pulsatilla pratensis, Sepia, Silica }\end{array}$ \\
\hline
\end{tabular}

\section{Homeopathic medicine}

Individualised

\section{Dilution* Study setting Funding}

D3-D12
Dilution

Not stated

$30 C$

All but one

components

potentised to

$12 C$ and higher
$(30 C, 200 C)$

$12 \mathrm{C}$

D5

Pulsatilla pratensis, Sepia, Silica

\section{D3 - D8}

\section{Study setting Funding}

Six farms in

Germany

Swine farm,

Brazil

Cattle farm,

Brazil

research

institution,

Brazil

Cattle farms,

Iran

Government

research

institution,

Brazil

Two horse

clinics in

Germany

(Berlin area,

Munich area)

D6

Thirteen

medicines
University

veterinary

ambulance; 2

swine herds in

Germany

(Berlin area)

Remedies were gift of the manufacture

\section{Government}

organic dai

herds,

EC grant; Weleda
'provided the

remedies'

Free from

vested interest

No

Directly funded study

(Heel Pharmacy)

The company,

Farmácia Sensitiva,

'supplied' the

None stated

None declared. The

homeopathic

laboratories, Flora \&

Fauna Ltd., supplied

the medicine

Richter Pharma

donated the

homeopathi

medicine

None stated

Study performed by

a contract research

organisation

Free from

vested interest

No

No

Switzerland 
Table 1 Demographic details of 20 OTP-controlled RCTs in veterinary homeopathy (Continued)

\begin{tabular}{|c|c|c|c|c|c|c|c|c|c|c|c|}
\hline Mastitis & Cattle & $\mathrm{A} 20$ & Varshney & 2005 & Active & Antibiotic & $\begin{array}{l}\text { Complex of } 8 \text { remedies: Healwell } \\
\text { VT-6 (Sintex International Limited, } \\
\text { Kalol, India), consisting of } \\
\text { Phytolacca, Calcarea fluorica, } \\
\text { Silica, Belladona, Bryonia, Arnica, } \\
\text { Conium, Ipecacuanha } \\
\text { "in equal amount" }\end{array}$ & $\begin{array}{l}\text { 200C: Phytolacca, } \\
\text { Calcarea fluorica. } \\
\text { 30c: Silica, } \\
\text { Belladona, Bryonia, } \\
\text { Arnica, Conium, } \\
\text { Ipecacuanha }\end{array}$ & $\begin{array}{l}\text { Dairy farm, } \\
\text { India }\end{array}$ & $\begin{array}{l}\text { Sintex International } \\
\text { Ltd 'supplied the } \\
\text { homeopathic } \\
\text { formulation for } \\
\text { clinical trial' }\end{array}$ & No \\
\hline $\begin{array}{l}\text { Mastitis, metritis } \\
\text { and agalactia }\end{array}$ & Pigs & A39 & Braun & 2011 & Active & Antibiotic & $\begin{array}{l}2 \text { complex preparations. Lachesis } \\
\text { compositum + Traumeel }\end{array}$ & Not stated & $\begin{array}{l}\text { Three piglet- } \\
\text { rearing farms } \\
\text { in Germany }\end{array}$ & $\begin{array}{l}\text { Directly funded study } \\
\text { (Heel Pharmacy) }\end{array}$ & No \\
\hline Pseudopregnancy & Dogs & A13 & Beceriklisoy & 2008 & Active & Naloxone & Thuja occidentalis/Urtica urens & D30 & $\begin{array}{l}\text { University } \\
\text { animal clinic, } \\
\text { Turkey }\end{array}$ & None stated & Unclear \\
\hline Salmonellosis & Birds & A18 & Sandoval & 1998 & Active & Antibiotic & Baptisia tinctoria & $30 C$ & $\begin{array}{l}\text { Poultry farm, } \\
\text { Mexico }\end{array}$ & None stated & Unclear \\
\hline $\begin{array}{l}\text { Gastrointestinal } \\
\text { nematodes }\end{array}$ & Sheep & A17 & Rocha & 2006 & $(A+B) v s . B$ & $\begin{array}{l}\text { Anthelmintic } \\
\text { only }\end{array}$ & Fator Vermes & Not stated & $\begin{array}{l}\text { University } \\
\text { establishment, } \\
\text { Brazil }\end{array}$ & None stated & Unclear \\
\hline \multicolumn{12}{|c|}{ iii: Non-individualised/Prophylaxis } \\
\hline Condition & Species & Ref. & First author & Year & Design & Control & Homeopathic medicine & Dilution & Study setting & Funding & $\begin{array}{l}\text { Free from } \\
\text { vested interest }\end{array}$ \\
\hline $\begin{array}{l}\text { Ectoparasite } \\
\text { infestation }\end{array}$ & Cattle & A34 & Signoretti & 2008 & $(A+B)$ vs. $B$ & $\begin{array}{l}\text { Protein } \\
\text { supplement } \\
\text { only }\end{array}$ & Factor $C \& M C C^{\oplus}: 16$ remedies & All $12 \mathrm{C}$ & $\begin{array}{l}\text { Government } \\
\text { research } \\
\text { institution, } \\
\text { Brazil }\end{array}$ & None stated & Unclear \\
\hline $\begin{array}{l}\text { Diarrhoea } \\
\text { (neonatal) }\end{array}$ & Pigs & A36 & Soto & 2008 & $(A+B)$ vs. $B$ & $\begin{array}{l}\text { Sucrose } \\
\text { saline } \\
\text { only }\end{array}$ & $\begin{array}{l}\text { Complex of } 4 \text { remedies: Echinacea } \\
\text { angustifolia, Avena sativa, Ignatia } \\
\text { amara, and Calcarea carbonica }\end{array}$ & $6 C$ & $\begin{array}{l}\text { Commercial } \\
\text { swine herd, } \\
\text { Brazil }\end{array}$ & None stated & Unclear \\
\hline Handling stress & Cattle & A31 & Reis & 2006 & $(A+B)$ vs. $B$ & $\begin{array}{l}\text { Mineral salt } \\
\text { only }\end{array}$ & Matricaria chamomilla ${ }^{\oplus}$ & $\begin{array}{l}12 C \text { (plus non } \\
\text { potentised sugar } \\
\text { and Bixa orellana } \\
\text { [grams]) }\end{array}$ & $\begin{array}{l}\text { Cattle farm, } \\
\text { Brazil }\end{array}$ & $\begin{array}{l}\text { "This research was } \\
\text { supported by the } \\
\text { Homeopathic } \\
\text { Laboratory Arenales } \\
\text { Flora \& Fauna Ltd." }\end{array}$ & No \\
\hline $\begin{array}{l}\text { Immune } \\
\text { response to } \\
\text { rabies } \\
\text { vaccination }\end{array}$ & Cattle & A32 & Reis & 2008 & $(A+B)$ vs. $B$ & $\begin{array}{l}\text { Mineral salt } \\
\text { only }\end{array}$ & Matricaria chamomilla ${ }^{\oplus}$ & $12 \mathrm{C}$ & $\begin{array}{l}\text { Cattle farm, } \\
\text { Brazil }\end{array}$ & $\begin{array}{l}\text { The homeopathic } \\
\text { laboratories, Flora \& } \\
\text { Fauna Ltd., are } \\
\text { thanked by the } \\
\text { author non-specifically }\end{array}$ & Unclear \\
\hline Infertility & Cattle & A35 & Sommer & 1972 & Untreated & Untreated & Complex of 5 remedies & D3-D5 & $\begin{array}{l}\text { Two cattle } \\
\text { farms, } \\
\text { University of } \\
\text { Hohenheim } \\
\text { (Germany) }\end{array}$ & None stated & Unclear \\
\hline
\end{tabular}

\section{iii: Non-individualised/Prophylaxis}


Table 1 Demographic details of 20 OTP-controlled RCTs in veterinary homeopathy (Continued)

\begin{tabular}{|c|c|c|c|c|c|c|c|c|c|c|c|}
\hline Infertility & Cattle & A38 & Williamson & 1991 & Untreated & Untreated & Sepia & $200 C$ & $\begin{array}{l}\text { Dairy herd, } \\
\text { Scotland }\end{array}$ & $\begin{array}{l}\text { British Cattle } \\
\text { Veterinary } \\
\text { Association. The } \\
\text { pharmacy, } \\
\text { Ainsworth's, are } \\
\text { thanked by the } \\
\text { authors non- } \\
\text { specifically }\end{array}$ & Unclear \\
\hline
\end{tabular}

*Note on homeopathic dilutions: The number refers to the number of successive serial dilutions to which the starting material has been subjected. The letter refers to the scale on which the dilution has been carried out: the letter D denotes the decimal method of dilution (that is, one part of liquid is added to nine parts of purified water, ethanol, glycerol or lactose); the letter C indicates the centesimal method (one part added to 99 parts of diluent). In homeopathic dilutions above 12C/D24 (10-24 molar) - beyond Avogadro's constant, $6.02 \times 10^{23} \mathrm{~mol}^{-1}$ - there are, in theory, no material traces of the original substance; such dilutions are known as 'ultra-molecular' 
Table 2 Sample sizes and outcomes for 20 OTP-controlled RCTs

i: Individualised/Treatment

Ref. First author Year $\mathrm{N}$ start $\mathrm{N}$ start $\mathrm{N}$ start $\mathrm{N}$ end $\mathrm{N}$ end $\mathrm{N}$ end $\% \quad$ Designated 'main (hom.) (cont.) (tot.) (hom.) (cont.) (tot.) Attrition outcome'
A12 Schütte
198833
31
33
$31 \quad 64$
0.0
Piglet mortality

Type of Direction of

Problem with

data change favouring designated 'main

homeopathy

outcome measure'

Dichot. Lower

Yes: Gives percentage

of dead piglets

(events) but not

number of piglets

born (total)

\section{ii: Non-individualised/Treatment}

Ref. First author Year $\mathrm{N}$ start $\mathrm{N}$ start $\mathrm{N}$ start $\mathrm{N}$ end $\mathrm{N}$ end $\mathrm{N}$ end $\% \quad$ Designated 'main (hom.) (cont.) (tot.) (hom.) (cont.) (tot.) Attrition outcome'

$\begin{array}{llllllllll}\text { A42 Lohr } & 2013 & 53 & 56 & 109 & 46 & 54 & 100 & 8.3 & \begin{array}{l}\text { Cure rate (Sum- } \\ \text { score (physical } \\ \text { condition)) }\end{array}\end{array}$

$\begin{array}{llllllllll}\text { A14 Coelho } & 2009 & 35 & 11 & 46 & 35 & 9 & 44 & 4.3 & \begin{array}{l}\text { Proportion of } \\ \text { animals without } \\ \text { diarrhoea at the } \\ \text { end of treatment }\end{array} \\ \text { A41 Catto } & 2013 & 72 & 36 & 108 & 72 & 36 & 108 & 0.0 & \end{array}$

Dichot. Higher

$\begin{array}{lll}\text { Type of } & \text { Direction of } & \text { Problem with } \\ \text { data } & \text { change favouring } & \text { designated 'main }\end{array}$

$\begin{array}{lll}\begin{array}{l}\text { Type of } \\ \text { data }\end{array} & \begin{array}{l}\text { Direction of } \\ \text { change favouring }\end{array} & \begin{array}{l}\text { Problem with } \\ \text { designated 'main }\end{array}\end{array}$

homeopathy outcome measure'

Dichot. Higher

Only 46 (Hom) and

54 (Cont) animals

regularly completed

the study, and are

therefore the data

for our calculations.

The authors themselves

calculated cure rate

based on 50 and

56 animals respectively.

201372

36

Faecal egg count

Contin. Lower

Yes: Unclear sample

Second year

sizes - see Notes

End-point Notes

Up to $4 d$

No

$12 d$

$\mathrm{N}=$ No. of sows

treated

tes 
Table 2 Sample sizes and outcomes for 20 OTP-controlled RCTs (Continued)

\begin{tabular}{|c|c|c|c|c|c|c|c|c|c|c|c|c|c|c|c|}
\hline A21 & Zacharias & 2008 & 7 & 7 & 14 & $? 7$ & $? 7$ & $? 14$ & Unclear & Faecal egg count & Contin. & Lower & $\begin{array}{l}\text { No. Numbers for } \\
\text { analysis interpolated } \\
\text { from Figure } 1 \mathrm{~A} \text {. } \\
\mathrm{N} \text { not stated for } \\
\text { endpoint, but } \\
\text { assumed to be } \mathrm{N}=7 \text {. }\end{array}$ & $68 d$ & $\begin{array}{l}\text { Disparity between } \\
\text { data (mean eggs } \\
\text { per gram) for } \\
\text { conv med group } \\
\text { given in text } \\
(1,483) \text { and by } \\
\text { inspection of Fig } 1 \\
(1,300 \text { approx.) }\end{array}$ \\
\hline A15 & Faulstich & 2006 & 24 & 22 & 46 & 22 & 19 & 41 & 10.9 & $\begin{array}{l}\text { Treatment success } \\
\text { (overall effectiveness) }\end{array}$ & Dichot. & Higher & $\begin{array}{l}\text { No : Numbers for } \\
\text { analysis from } \\
\text { percentage data } \\
\text { in Table } 9\end{array}$ & $21 d$ & $\begin{array}{l}\text { Control really } \\
\text { active? }\end{array}$ \\
\hline A16 & Klocke & 2010 & 32 & 36 & 68 & 32 & 36 & 68 & 0.0 & $\begin{array}{l}\text { Absence of clinical } \\
\text { mastitis infection }\end{array}$ & Dichot. & Higher & $\begin{array}{l}\text { No: Data derived } \\
\text { from text of Results } \\
\text { [line 6]) }\end{array}$ & $\begin{array}{l}\text { First } 100 \text { days } \\
\text { post-calving }\end{array}$ & \\
\hline $\mathrm{A} 20$ & Varshney & 2005 & 67 & 96 & 163 & 67 & 96 & 163 & 0.0 & $\begin{array}{l}\text { Quarter cure-rate } \\
\text { (non-fibrosed) }\end{array}$ & Dichot. & Higher & $\begin{array}{l}\text { No : Numbers for } \\
\text { analysis from } \\
\text { percentage data } \\
\text { in Table } 2\end{array}$ & Up to $28 \mathrm{~d}$ & $\begin{array}{l}\mathrm{N}=\text { quarters, } \\
\text { not animals }\end{array}$ \\
\hline A39 & Braun & 2011 & 30 & 34 & 64 & 28 & 32 & 60 & 6.3 & $\begin{array}{l}\text { Cure rate } \\
\text { (MMA-sum score) }\end{array}$ & Dichot. & Higher & & $\begin{array}{l}\text { Up to } 4 d(H) \\
\text { or } 3 d(C)\end{array}$ & \\
\hline A13 & Beceriklisoy & 2008 & 30 & 8 & 38 & 30 & 8 & 38 & 0.0 & $\begin{array}{l}\text { Treatment 'success' } \\
\text { (recovery rate) }\end{array}$ & Dichot. & Higher & No & Up to $20 \mathrm{~d}$ & \\
\hline A18 & Sandoval & 1998 & 200 & 200 & 400 & 200 & 200 & 400 & 0.0 & $\begin{array}{l}\text { Cumulative total } \\
\text { mortality } \\
\text { (1st quality broilers) }\end{array}$ & Contin. & Lower & $\begin{array}{l}\text { Yes: Data are } \\
\text { presented as } \\
\text { accumulated } \\
\text { mortality - not } \\
\text { amenable to } \\
\text { meta-analysis }\end{array}$ & $49 d$ & $\begin{array}{l}\mathrm{N}=1 \text { st quality } \\
\text { broilers }\end{array}$ \\
\hline A17 & Rocha & 2006 & 10 & 10 & 20 & 10 & 10 & 20 & 0.0 & $\begin{array}{l}\text { Proportion of animals } \\
\text { not requiring anti- } \\
\text { helminthic treatment }\end{array}$ & Dichot. & Higher & $\begin{array}{l}\text { No: Data derived } \\
\text { from text of Results } \\
\text { (second paragraph) }\end{array}$ & $\begin{array}{l}4 \text { mo } \\
\text { (first phase) }\end{array}$ & \\
\hline \multicolumn{16}{|c|}{ iii: Non-individualised/Prophylaxis } \\
\hline Ref. & First author & Year & $\begin{array}{l}\text { N start } \\
\text { (hom.) }\end{array}$ & $\begin{array}{l}\mathrm{N} \text { start } \\
\text { (cont.) }\end{array}$ & $\begin{array}{l}\mathrm{N} \text { start } \\
\text { (tot.) }\end{array}$ & $\begin{array}{l}\mathrm{N} \text { end } \\
\text { (hom.) }\end{array}$ & $\begin{array}{l}\mathrm{N} \text { end } \\
\text { (cont.) }\end{array}$ & $\begin{array}{l}\mathrm{N} \text { end } \\
\text { (tot.) }\end{array}$ & $\begin{array}{l}\% \\
\text { Attrition }\end{array}$ & $\begin{array}{l}\text { Designated 'main } \\
\text { outcome' }\end{array}$ & $\begin{array}{l}\text { Type of } \\
\text { data }\end{array}$ & $\begin{array}{l}\text { Direction of } \\
\text { change favouring } \\
\text { homeopathy }\end{array}$ & $\begin{array}{l}\text { Problem with } \\
\text { designated 'main } \\
\text { outcome measure' }\end{array}$ & End-point & Notes \\
\hline A34 & Signoretti & 2008 & 8 & 8 & 16 & $? 8$ & $? 8$ & $? 16$ & Unclear & $\begin{array}{l}\text { Faecal egg count } \\
\text { per gram }\end{array}$ & Contin. & Lower & $\begin{array}{l}\text { No. But assumes } \\
\text { zero attrition rate. } \\
\text { Data from Table } 3 .\end{array}$ & $30 d$ & \\
\hline A36 & Soto & 2008 & 24 & 24 & 48 & 24 & 24 & 48 & 0.0 & $\begin{array}{l}\text { Number of } \\
\text { animal-days } \\
\text { with diarrhoea }\end{array}$ & Dichot. & Lower & $\begin{array}{l}\text { No. But relate 7-day } \\
\text { cumulated data to } \\
\text { total possible number } \\
\text { of animal-days per } \\
\text { group }\end{array}$ & $7 d$ period & $\begin{array}{l}\text { Hom plus sucrose } \\
\text { saline vs. sucrose } \\
\text { saline only }\end{array}$ \\
\hline
\end{tabular}


Table 2 Sample sizes and outcomes for 20 OTP-controlled RCTs (Continued)

\begin{tabular}{|c|c|c|c|c|c|c|c|c|c|c|c|c|c|c|c|}
\hline A31 & Reis & 2006 & 30 & 30 & 60 & 30 & 30 & 60 & 0.0 & Serum cortisol & Contin. & Lower & $\begin{array}{l}\text { No. Assumes zero } \\
\text { attrition rate based } \\
\text { on legend for } \\
\text { Figure } 1 .\end{array}$ & $60 d$ & $\begin{array}{l}\text { Hom plus mineral } \\
\text { salt vs. mineral } \\
\text { salt only }\end{array}$ \\
\hline A32 & Reis & 2008 & 15 & 15 & 30 & 15 & $? 15$ & $? 30$ & Unclear & $\begin{array}{l}\text { Rabies-neutralizing } \\
\text { antibody titer }\end{array}$ & Contin. & Higher & $\begin{array}{l}\text { No. But assumes } \\
\text { zero attrition rate. }\end{array}$ & $\begin{array}{l}60 \mathrm{~d} \text { after } \\
\text { vaccination }\end{array}$ & $\begin{array}{l}\text { Compares Group } \\
\text { FEV2 (Hom + salt) } \\
\text { with Group V2 } \\
\text { (salt only) }\end{array}$ \\
\hline A35 & Sommer & 1972 & 40 & 18 & 58 & 40 & 18 & 58 & 0.0 & $\begin{array}{l}\text { Number with } \\
\text { infertility disorders }\end{array}$ & Dichot. & Lower & No. Data from table 2 & Not stated & \\
\hline A38 & Williamson & 1991 & 101 & 32 & 133 & $? 100$ & $? 32$ & $? 132$ & Unclear & $\begin{array}{l}\text { Number with } \\
\text { peripartum disorders }\end{array}$ & Dichot. & Lower & $\begin{array}{l}\text { Yes: Unclear } \\
\text { tabulations }\end{array}$ & None & \\
\hline
\end{tabular}


Table 3 Risk-of-bias assessments for 20 OTP-controlled RCTs

i: Individualised/Treatment

Ref. First author Domain I Domain II Domain IIIA Domain IIIB Domain IV Domain V Domain VI (excl. fund) No. of domains for which Risk of bias (excl. vested interest)

Reliable evidence criteria fulfilled Y U N

$\begin{array}{lllllllllllll}\text { A12 Schütte } & N & N & N & N & \text { N } & \text { N } & \text { U } & 1 & 1 & 5\end{array}$

\section{ii: Non-individualised/Treatment}

Ref. First author Domain I Domain II Domain IIIA Domain IIIB Domain IV Domain V Domain VI (excl. fund) No. of domains for which Risk of bias

A42 Lohr

A14 Coelho

A41 Catto

A19 Silva

A40 Lotfollahzadeh $U$

A21 Zacharias

A15 Faulstich

A16 Klocke

A20 Varshney

A39 Braun

A13 Beceriklisoy

A18 Sandoval

A17 Rocha

iii: Non-individualised/Prophylaxis
IA Domain IIIB Domain IV Domain V Domain VI (excl. fund) $\begin{aligned} & \text { No. of domains } \\ & \text { criteria fulfilled }\end{aligned}$ Y U N

$3 \quad 1 \quad 3$

$\begin{array}{lll}3 & 1 & 3 \\ 2 & 3 & 2\end{array}$

$0 \quad 5 \quad 2$

$\begin{array}{lll}0 & 5 & 2\end{array}$

2

2

1
5

4

1

4

4
1

0

0
2 (excl. vested interest)

Reliable evidence

$\begin{array}{ll}\text { High } & \text { No } \\ \text { High } & \text { No } \\ \text { High } & \text { No } \\ \text { High } & \text { No } \\ \text { High } & \text { No } \\ \text { High } & \text { No } \\ \text { High } & \text { No } \\ \text { High } & \text { No } \\ \text { High } & \text { No } \\ \text { High } & \text { No } \\ \text { High } & \text { No } \\ \text { High } & \text { No } \\ \text { High } & \text { No }\end{array}$

Ref. First author Domain I Domain II Domain IIIA Domain IIIB Domain IV Domain V Domain VI (excl. fund) No. of domains for which Risk of bias

(excl. vested interest)

Reliable evidence criteria fulfilled

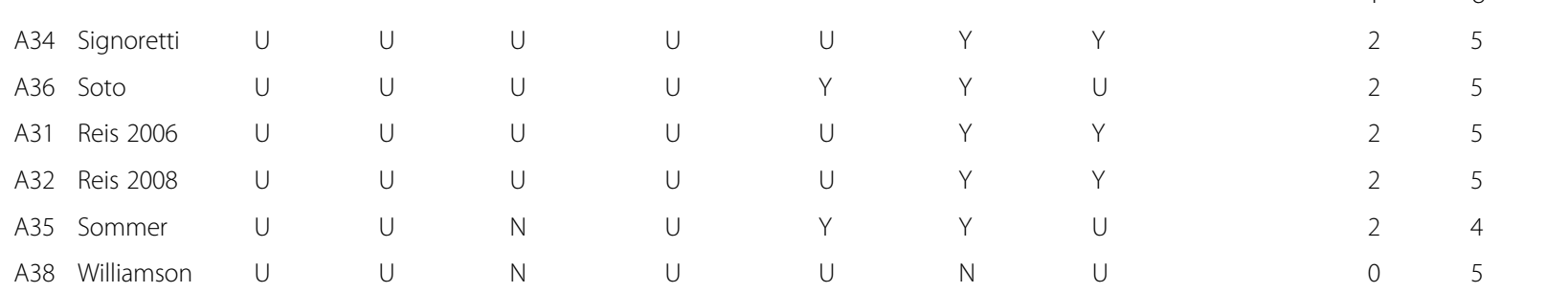

$\begin{array}{ll}\text { Uncertain } & \text { No } \\ \text { Uncertain } & \text { No } \\ \text { Uncertain } & \text { No } \\ \text { Uncertain } & \text { No } \\ \text { High } & \text { No } \\ \text { High } & \text { No }\end{array}$

Domains I-VI are explained in the main text. Criteria fulfilled for domains: $\mathrm{Y}=\mathrm{Yes} ; \mathrm{U}=$ Unclear; $\mathrm{N}=\mathrm{No}$ 


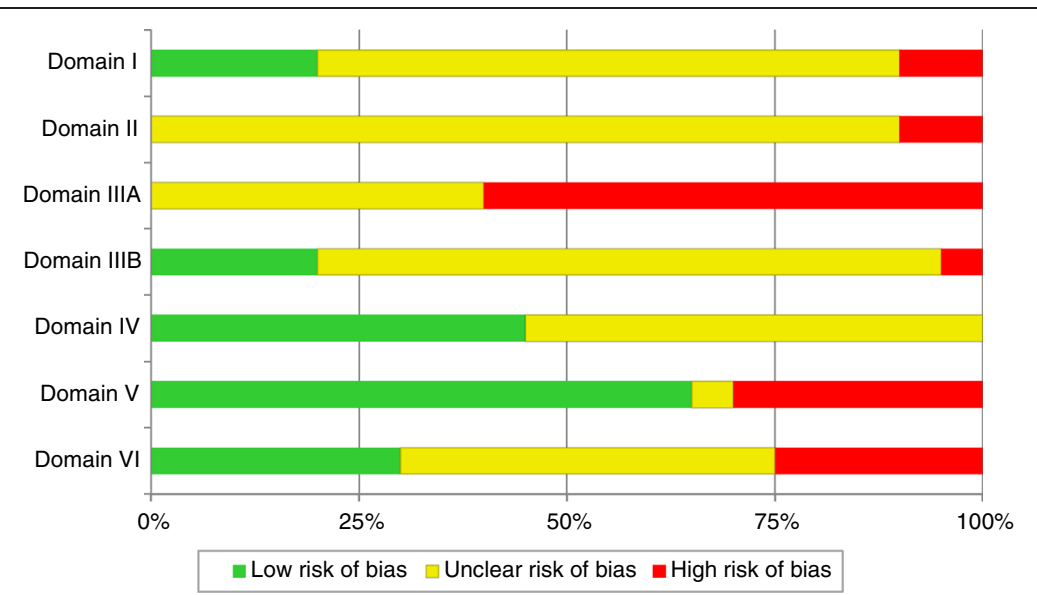

Fig. 1 Risk-of-bias summary graph. Illustrates, for each assessment domain, the proportion of RCTs with low, unclear and high risk of bias

and so in each case it was statistically inconclusive whether homeopathy combined with conventional intervention was more or was less effective than conventional intervention alone - see Table 4a.

\section{Trials at high risk of bias}

Data could not be extracted from the single paper on individualised treatment. Data were extractable from 10 of the 13 relevant RCTs of non-individualised treatment; the direction of effect statistically significantly favoured homeopathy in four of the ten cases - see Table $4 \mathrm{~b}$. Two of these four yielded what appear to be spuriously high mean OR values (A13, Bekeriklisoy 2008: OR $=95.86 ;$ A14, Coelho 2009: OR =58.09). Of the two RCTs of non-individualised prophylaxis (both with untreated controls), data were extractable from one (A35, Sommer 1972).

\section{Discussion}

This comprehensive systematic review of the peerreviewed literature has revealed no OTP-controlled RCT of veterinary homeopathy that comprised reliable evidence. Our main conclusions from this study are therefore restricted to the findings of three RCTs, whose quality was unclear and whose methodological diversity contraindicated meta-analysis. Each of these three trials is in the category of non-individualised homeopathic prophylaxis (A32, Reis 2008; A34, Signoretti 2008; A36, Soto 2008), a prescribing approach that some homeopathic practitioners might view as controversial [22]. Each of the three trials is also in the adjunctive category, and manifested statistically inconclusive findings: this result undermines the suggestion that the ' $[A+B]$ versus B' study design can 'generate only positive results' [23].

For each of the above three trials, the uncertainty regarding risk of bias was so marked that their findings must be viewed with extreme caution. Given the lack of clarity in so many domains of assessment, this degree of concern would still apply even if we had reflected more leniently the fact that non-blinding of study personnel is a typical feature of an OTP-controlled trial. The admissible evidence in veterinary homeopathy for this study design is therefore unable to provide any compelling information about modulation of immune response in calves (A32, Reis 2008) or adjunctive prophylaxis of cattle tick (A34, Signoretti 2008) or of diarrhoea in piglets (A36, Soto 2008).

In assessing all the studies, we had reason on occasions to question the veracity of the control group as an 'active' or effective intervention (e.g. mineral or protein supplements, or naloxone in pseudopregnancy), and so raised doubts about the 'other than placebo' nature of some of the included trials. We were careful not to attribute 'equivalence' to superiority trials that found no statistically significant difference between homeopathy and active control $[16,19]$.

For OTP-controlled RCTs of non-individualised homeopathic treatment, there is nothing that we can reasonably conclude, given that each one of the trials was judged to be at high risk of bias. Thus, the positive inference we attributed to four trials in this category cannot be regarded as admissible evidence; the spuriously large treatment effect evidenced in two of the trials reinforces those serious concerns. It remains unknown whether non-individualised homeopathy is effective in the prophylaxis of fertility disorders in cattle. Likewise, no conclusions can be made regarding individualised homeopathic treatment, since the single trial in this category was of very low quality and yielded no extractable data for analysis.

Our most recent literature search, conducted during the process of the current paper's peer-review, revealed 
Table 4 Summary statistics for: (a) trials at uncertain risk of bias; (b) trials at high risk of bias

\section{a) UNCERTAIN RISK OF BIAS}

iii: Non-individualised/Prophylaxis

Ref. First author Year Condition

\section{Species Outcome measure Hom. Cont.}

\section{Summary}

Effect size Direction of Direction $P$

Inference*

effect measure $(95 \% \mathrm{Cl})$ change favouring of effect value homeopathy

\begin{tabular}{|c|c|c|c|c|c|c|c|c|c|c|c|c|}
\hline A34 Signoretti & 2008 & Ectoparasite infestation & Cattle & $\begin{array}{l}\text { Faecal egg count } \\
\text { per gram }\end{array}$ & $\begin{array}{l}340(s d, 214) \\
N=8\end{array}$ & $\begin{array}{l}207(s d, 131) ; \\
N=8\end{array}$ & SMD & $\begin{array}{l}0.71[-0.31 \\
1.73]\end{array}$ & Lower & Cont. & 0.17 & [iii: b] \\
\hline A36 Soto & 2008 & Diarrhoea (neonatal) & Pigs & $\begin{array}{l}\text { Number of } \\
\text { animal-days } \\
\text { with diarrhoea }\end{array}$ & $34 / 192$ & $25 / 192$ & OR & $\begin{array}{l}0.70[0.40, \\
1.22]\end{array}$ & Lower & Cont. & 0.20 & [iii: b] \\
\hline Reis & 2006 & Handling stress & Cattle & Serum cortisol & $\begin{array}{l}5.1(s d, 1.8) ; \\
N=30\end{array}$ & $\begin{array}{l}5.3(s d, 1.45) \\
N=30\end{array}$ & $S M D$ & $\begin{array}{l}-0.12 \\
{[-0.63,0.39]}\end{array}$ & Lower & Hom. & 0.64 & [iii: b] \\
\hline A32 Reis & 2008 & $\begin{array}{l}\text { Immune response } \\
\text { to rabies vaccination }\end{array}$ & Cattle & $\begin{array}{l}\text { Rabies-neutralizing } \\
\text { antibody titer }\end{array}$ & $\begin{array}{l}10.8(\mathrm{sd}, 9.5) ; \\
N=15\end{array}$ & $\begin{array}{l}14.4(\mathrm{sd}, 11.1) ; \\
\mathrm{N}=15\end{array}$ & SMD & $\begin{array}{l}-0.34 \\
{[-1.06,0.38]}\end{array}$ & Higher & Cont. & 0.36 & [iii: b] \\
\hline
\end{tabular}

\section{b) HIGH RISK OF BIAS}

i: Individualised/Treatment

Ref. First author Year Condition

Species Outcome measure Hom.

Cont.

Pigs None useable $\quad x$

$$
\text { and agalactia }
$$

A12 Schütte

ii: Non-individualised/Treatment

Ref. First author Year Condition

\begin{tabular}{|c|c|c|c|}
\hline A42 & Lohr & 2013 & $\begin{array}{l}\text { Diarrhoea } \\
\text { (neonatal) }\end{array}$ \\
\hline A14 & Coelho & 2009 & $\begin{array}{l}\text { Diarrhoea } \\
\text { (neonatal) }\end{array}$ \\
\hline A41 & Catto & 2013 & $\begin{array}{l}\text { Ectoparasite } \\
\text { infestation }\end{array}$ \\
\hline A19 & Silva & 2008 & $\begin{array}{l}\text { Ectoparasite } \\
\text { infestation }\end{array}$ \\
\hline A4O & Lotfollahzadeh & 2012 & $\begin{array}{l}\text { Foot-and-mouth } \\
\text { disease }\end{array}$ \\
\hline A21 & Zacharias & 2008 & $\begin{array}{l}\text { Gastrointestinal } \\
\text { nematodes }\end{array}$ \\
\hline 15 & Faulstich & 2006 & Lameness \\
\hline
\end{tabular}

\section{Species Outcome measure Hom}

$$
\text { Pigs }
$$

without diarrhoea at

Cattle None useable

Cattle None useable

Cattle Rectal temperature

Sheep Faecal egg count

Horses
Proportion of animals 35/35

the end of treatment

$$
\begin{array}{ll}
38.6(\mathrm{sd}, 0.2), \quad & 39.0(\mathrm{sd}, \\
\mathrm{N}=50 & \mathrm{~N}=15
\end{array}
$$

$\mathrm{N}=7$

(overall effectiveness)
$18 / 22 \quad 14 / 19$

$\begin{aligned} & \text { Summ } \\ & \text { effect } m \\ & x\end{aligned}$
Summ
effect

Summary

Effect size Direction of

Direction $P \quad$ Inference $^{a}$ change favouring of effect value homeopathy

x

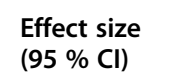

\section{Direction of of effect valu \\ Inference*} change favourin

Higher

Cont

0.91 [iii: a]

$2.28]$

58.09 [2.73, Higher

Hom. 0.009 [i: a]

1234.82]

$\begin{array}{ll}x & x \\ x & x\end{array}$

$x$

$-2.16[-2.86$, Lower $-1.47]$

$-0.30[-1.36$, Lower

$0.75]$

$1.61[0.36$, Higher

7.12] 
Table 4 Summary statistics for: (a) trials at uncertain risk of bias; (b) trials at high risk of bias (Continued)

\begin{tabular}{|c|c|c|c|c|c|c|c|c|c|c|c|c|c|}
\hline A16 & Klocke & 2010 & Mastitis & Cattle & $\begin{array}{l}\text { Absence of clinical } \\
\text { mastitis infection }\end{array}$ & $29 / 32$ & $32 / 36$ & $O R$ & $\begin{array}{l}1.21[0.25 \\
5.86]\end{array}$ & Higher & Hom. & 0.81 & [iii: a] \\
\hline$A 20$ & Varshney & 2005 & Mastitis & Cattle & $\begin{array}{l}\text { Quarter cure-rate } \\
\text { (non-fibrosed) }\end{array}$ & $58 / 67$ & $57 / 96$ & $O R$ & $\begin{array}{l}4.41[1.96, \\
9.93]\end{array}$ & Higher & Hom. & $<0.001$ & [i: a] \\
\hline A39 & Braun & 2011 & $\begin{array}{l}\text { Mastitis, metritis } \\
\text { and agalactia }\end{array}$ & Pigs & $\begin{array}{l}\text { Cure rate } \\
\text { (MMA-sum score) }\end{array}$ & $20 / 28$ & $21 / 32$ & $O R$ & $\begin{array}{l}1.31[0.44, \\
3.92]\end{array}$ & Higher & Hom. & 0.63 & [iii: a] \\
\hline A13 & Beceriklisoy & 2008 & Pseudopregnancy & Dogs & $\begin{array}{l}\text { Treatment 'success' } \\
\text { (recovery rate) }\end{array}$ & $30 / 30$ & $3 / 8$ & OR & $\begin{array}{l}95.86[4.32 \\
2126.07]\end{array}$ & Higher & Hom. & 0.004 & [i: a] \\
\hline A18 & Sandoval & 1998 & Salmonellosis & Birds & None useable & $x$ & $x$ & $x$ & $x$ & $x$ & $x$ & $x$ & $x$ \\
\hline A17 & Rocha & 2006 & $\begin{array}{l}\text { Gastrointestinal } \\
\text { nematodes }\end{array}$ & Sheep & $\begin{array}{l}\text { Proportion of animals } \\
\text { not requiring } \\
\text { anti-helminthic } \\
\text { treatment }\end{array}$ & $7 / 10$ & $5 / 10$ & $\mathrm{OR}$ & $\begin{array}{l}2.33[0.37 \\
14.61]\end{array}$ & Higher & Hom. & 0.37 & [iii: b] \\
\hline \multicolumn{14}{|c|}{ iii: Non-individualised/Prophylaxis } \\
\hline Ref. & First author & Year & Condition & Species & Outcome measure & Hom. & Cont. & $\begin{array}{l}\text { Summary } \\
\text { effect measure }\end{array}$ & $\begin{array}{l}\text { Effect size } \\
(95 \% \mathrm{Cl})\end{array}$ & $\begin{array}{l}\text { Direction of } \\
\text { change favouring } \\
\text { homeopathy }\end{array}$ & $\begin{array}{l}\text { Direction } \\
\text { of effect }\end{array}$ & $\begin{array}{l}P \\
\text { value }\end{array}$ & Inference ${ }^{a}$ \\
\hline A35 & Sommer & 1972 & Infertility & Cattle & $\begin{array}{l}\text { Number with } \\
\text { infertility disorders }\end{array}$ & $13 / 40$ & $9 / 18$ & OR & $\begin{array}{l}2.08[0.67, \\
6.47]\end{array}$ & Lower & Hom. & 0.21 & [iii: c] \\
\hline A38 & Williamson & 1991 & Infertility & Cattle & None useable & $x$ & $x$ & $x$ & X & $x$ & X & $x$ & $x$ \\
\hline
\end{tabular}

Hom. $=$ homeopathy. Cont. $=$ control. $\mathrm{Cl}=$ confidence interval. $s \mathrm{~d}=$ standard deviation. $\mathrm{SMD}=$ standardised mean difference. $\mathrm{OR}=$ odds ratio

Italic text indicates trials with a potential risk of bias due to funding source (see also Table 1)

anference from the statistical findings is given by reference to the numbered study designs in Methods: Direction of effect of treatment/prophylaxis per trial 
only one further OTP-controlled trial that would potentially have been eligible for inclusion [21]. Notwithstanding normal concerns over the possibility that publication bias may have limited the number of 'negative' studies available, the present systematic review seems barely compromised by selection bias due to absence of relevant data.

Thus, the sum of the reliable peer-reviewed RCT evidence in veterinary homeopathy (out of 18 placebocontrolled and 20 OTP-controlled RCTs in total) comprises the two placebo-controlled trials that we previously identified $[2,3]$. Evidence concerning the effective use of homeopathy in animals remains indecisive.

\section{Conclusions}

Due to their extremely poor quality, OTP-controlled trials are incapable of providing useful additional insight into the effectiveness of homeopathic treatment or prophylaxis in animals. To clarify the matter, new and substantially improved OTP-controlled research in both individualised and non-individualised veterinary homeopathy is strongly indicated.

\section{Additional files}

\section{Additional file 1: PRISMA 2009 Checklist. (DOC 64 kb)}

Additional file 2: PRISMA flowchart, illustrating records of RCTs that are eligible and ineligible for inclusion in the systematic review. * Records are numbered as per a previous paper published by the authors (Mathie et al., 2012) [1]. Papers presented in italics are those identified in the follow-up literature search. Excluded papers are shown in red. \# RCT with continuous measure as main outcome (each unmarked trial has a dichotomous measure as the main outcome). (DOC $66 \mathrm{~kb}$ )

\section{Abbreviations}

CAB: Commonwealth Agricultural Bureaux; Cl: Confidence Interval; OR: Odds ratio; OTP: Other than placebo; PRISMA: Preferred reporting items for systematic reviews and meta-analyses; RCT: Randomised controlled trial; SMD: Standardised mean difference.

\section{Competing interests}

RTM and JC are each employed by a homeopathy charity to clarify and extend an evidence base in homeopathy; they have no other relationships or activities that could appear to have influenced the submitted work. The authors declare that they have no competing interests.

\section{Authors' contributions}

RTM devised and led the study, and undertook the primary write-up of the paper. Both authors developed the study protocol and contributed to all facets of the work; both take responsibility for the integrity of the data. Each author contributed to editing the manuscript and agreed the final version. RTM is guarantor.

\section{Authors' information}

As a research physiologist (RTM) and a biologist (JC), we have applied the normal high standards of scientific method in the conduct of the work and of complete and transparent reporting in the write-up of the paper.

\section{Sources of funding}

None.

\section{Author details}

'British Homeopathic Association, Hahnemann House, 29 Park Street West, Luton LU1 3BE, UK. ' Karl und Veronica Carstens-Stiftung, Am Deimelsberg 36, D-45276 Essen, Germany.

Received: 22 July 2015 Accepted: 13 August 2015

Published online: 15 September 2015

References

1. Mathie RT, Hacke D, Clausen J. Randomised controlled trials of veterinary homeopathy: Characterising the peer-reviewed research literature for systematic review. Homeopathy. 2012;101:196-203.

2. Mathie RT, Clausen J. Veterinary homeopathy: systematic review of medical conditions studied by randomised placebo-controlled trials. Vet Rec. 2014;175:373-81.

3. Mathie RT, Clausen J. Veterinary homeopathy: meta-analysis of randomised placebo-controlled trials. Homeopathy. 2015:104:3-8.

4. Higgins JPT, Altman DG (Eds): Assessing risk of bias in included studies. In: Cochrane Handbook for Systematic Reviews of Interventions, Version 5.1.0. Edited by Higgins JPT, Green S (Eds). The Cochrane Collaboration; 2011: Chapter 8.

5. Liberati A, Altman DG, Tetzlaff J, Mulrow C, Gøtzsche PC, loannidis JPA, et al. The PRISMA statement for reporting systematic reviews and meta-analyses of studies that evaluate health care interventions: Explanation and elaboration. J Clin Epidemiol. 2009;62:e1-e34.

6. Mathie RT, Legg LA, Clausen J, Davidson JRT, Lloyd SM, Ford I: Systematic review and meta-analysis of randomised, placebocontrolled, trials of individualised homeopathic treatment: study protocol. 2013, Version 1.0; 25 January 2013. www.britishhomeopathic.org/ wp-content/uploads/2013/05/Study_protocol_for_systematic_review.pdf (Accessed 19 April, 2013).

7. Mathie RT, Lloyd SM, Legg LA, Clausen J, Moss S, Davidson JRT, et al, Randomised placebo-controlled trials of individualised homeopathic treatment: systematic review and meta-analysis. Syst Rev. 2014;3:142.

8. Grindlay DJC, Brennan ML, Dean RS. Searching the veterinary literature: A comparison of the coverage of veterinary journals by nine bibliographic databases. J Vet Med Educ. 2012;39:404-12.

9. Higgins JPT, Deeks JJ, Altman DG (Eds): Special topics in statistics. In: Cochrane Handbook for Systematic Reviews of Interventions, Version 5.1.0. Edited by Higgins JPT, Green S (Eds). The Cochrane Collaboration; 2011: Chapter 16.

10. Linde K, Clausius N, Ramirez G, Melchart D, Eitel F, Hedges LV, et al. Are the clinical effects of homeopathy placebo effects? A meta-analysis of placebocontrolled trials. Lancet. 1997:350:834-43.

11. Shang A, Huwiler-Müntener $K$, Nartey $L$, Jüni $P$, Dörig $S$, Sterne JAC, et al Are the clinical effects of homoeopathy placebo effects? Comparative study of placebo-controlled trials of homoeopathy and allopathy. Lancet. 2005:366:726-32

12. World Health Organization: Towards a Common Language for Functioning, Disability and Health: ICF - The International Classification of Functioning, Disability and Health. World Health Organization, 2002. www.who.int/classifications/icf/training/icfbeginnersguide.pdf (Accessed 19 April, 2013).

13. Dmitrienko A, D'Agostino Sr RB, Huque MF. Key multiplicity issues in clinical drug development. Stat Med. 2013;32:1079-111.

14. Deeks JJ, Higgins JPT, Altman DG (Eds): Analysing data and undertaking meta-analyses. In: Cochrane Handbook for Systematic Reviews of Interventions, Version 5.1.0. Edited by Higgins JPT, Green S (Eds). The Cochrane Collaboration; 2011: Chapter 9.

15. Sedgwick P. What is a superiority trial? BMJ. 2013:347:f5420

16. Sedgwick P. Equivalence trials. BMJ. 2013;346:f184.

17. Sedgwick P. What is a non-inferiority trial? BMJ. 2013:347:f6853.

18. Dent L, Raftery J. Treatment success in pragmatic randomised controlled trials: a review of results funded by the UK Health Technology Assessment programme. Trials. 2011;12:109.

19. Wellek S, Blettner M. Establishing equivalence or non-inferiority in clinical trials. Dtsch Arztebl Int. 2012;109:674-9.

20. Stovold E, Beecher D, Foxlee R, Noel-Storr A. Study flow diagrams in Cochrane systematic review updates: an adapted PRISMA flow diagram. Syst Rev. 2014;3:54

21. Kiefer C, Rizzardi R, de Oliveira BF, Silva CM, Martins LP, Fantini CC. Complexo homeopático na prevenção e tratamento de diarréias em 
leitões lactentes [Homeopathic complex in the prevention and treatment of diarrhoea in suckling piglets]. Rev Bras Saúde Prod Anim. 2012;13:74-82.

22. Hoover TA: Epidemic diseases and homeopathic prophylaxis: fact or fiction. http://toddhoovermd.com/articles/epidemic-diseases-andhomeopathic-prophylaxis.html (Accessed, 26 June 2014).

23. Ernst E, Lee MS. A trial design that generates only 'positive' results. J Postgrad Med. 2008;54:214-6.

Submit your next manuscript to BioMed Central and take full advantage of:

- Convenient online submission

- Thorough peer review

- No space constraints or color figure charges

- Immediate publication on acceptance

- Inclusion in PubMed, CAS, Scopus and Google Scholar

- Research which is freely available for redistribution 